\title{
SHRIMP U-Pb dating of detrital zircons in paragneiss from Oki-Dogo Island, western Japan
}

\author{
Yukiyasu TsuTsumi ${ }^{*}$, Kazumi YoKoYAma*, Kenji HoRIE**, \\ Kentaro TERADA** and Hiroshi HIDAKA** \\ *Department of Geology, National Science Museum, Shinjuku-ku, Tokyo 169-0073, Japan \\ ** Department of Earth and Planetary Sciences, Graduate School of Science, \\ Hiroshima University, Higashi-Hiroshima, Hiroshima, 739-8526, Japan
}

\begin{abstract}
We obtained the radiometric ages of detrital zircons from two samples of paragneiss from Oki-Dogo Island, Japan, from the ${ }^{238} \mathrm{U} /{ }^{206} \mathrm{~Pb}$ ratio and isotopic composition of $\mathrm{Pb}$ determined using a Sensitive High-Resolution Ion MicroProbe (SHRIMP II). The zircons show two main age clusters around $2200 \mathrm{Ma}$ and $1800 \mathrm{Ma}$, with some discordant ages. One zircon grain has a rim with a concordant age of $236 \pm 3 \mathrm{Ma}$, which is consistent with the age of peak metamorphism in the Hida Metamorphic Belt. The modal proportions of zircon ages from OkiDogo Island are clearly different from those for paragneiss of the Hida Terrane. This indicates that the Oki Gneiss is derived from an Early Proterozoic rock and is different from the Hida Gneiss in terms of provenance and/or the depositional age of the parent sediment.
\end{abstract}

Keywords: Oki Islands, Paragneiss, Provenance, Detrital zircon, U-Pb age

\section{INTRODUCTION}

The Hida Belt is located in the northern part of southwest Japan, and consists of low- to medium-P/T gneisses that were metamorphosed at approximately 240 to $250 \mathrm{Ma}$ (Ishizaka and Yamaguchi, 1969; Ota and Itaya, 1989; Suzuki and Adachi, 1991). The gneisses were once considered to form the basement of the Japanese Islands, which originally formed during the Precambrian (Sato, 1968). Otofuji et al. (1983) demonstrated from paleomagnetic data that the Sea of Japan opened during the Middle Miocene, and many researchers consider that the Hida Metamorphic Belt was formed by continental collision between the Sino-Korean and Yangtze Massifs, as determined from lithofacies analysis (Hiroi, 1981; Maruyama and Seno, 1986; Isozaki and Maruyama, 1991; Ree, 1996), or between the Sino-Korean and Siberia Massifs (Arakawa et al., 2000). These interpretations require that part of the Hida Belt was connected to the Ogcheon Belt (Hiroi, 1981) or the Imjingang Belt (Ree et al., 1996)

doi:10.2465/jmps.060127

Y. Tsutsumi, ytsutsu@kahaku.go.jp Corresponding author

K. Yokoyama, yokoyama@kahaku.go.jp

K. Horie, kenjih@hiroshima-u.ac.jp

H. Hidaka, hidaka@letitbe.geol.sci.hiroshima-u.ac.jp

K.Terada, terada@sci.hiroshima-u.ac.jp prior to the opening of the Sea of Japan (Fig. 1).

The gneiss on Oki-Dogo Island is considered to be a western extension of the Hida Gneiss on the basis of similarities in both lithofacies and metamorphic age. Wholerock isochron ages in excess of 1800 Ma have been reported for the Oki Gneiss (Tanaka and Hoshino, 1987), and are interpreted to represent the age of the source rocks. Such old ages have not previously been reported for gneisses of the Hida district (cf., Ota and Itaya, 1989). In contrast, Suzuki and Adachi (1994) analyzed the ages of zircon and monazite grains from paragneisses on OkiDogo Island using an electron microprobe analyzer and concluded that the depositional age of the parent sediments is less than 350 Ma. Sano et al. (2000) analyzed zircons in paragneisses from the Amo area, Hida district, using SHRIMP II, and on the basis of age variations from 240 to 3000 Ma concluded that the depositional age of the parent sediment was approximately $250 \mathrm{Ma}$.

To clarify the depositional age of the parent rocks of paragneisses on Oki-Dogo Island, we analyzed zircons from two paragneiss samples and measured $\mathrm{U}-\mathrm{Pb}$ ages using SHRIMP II equipment installed at Hiroshima University, Japan. The closure temperature of the $\mathrm{U}-\mathrm{Pb}$ system in zircon is higher than $900{ }^{\circ} \mathrm{C}$, and the system usually remains closed under low- to medium-grade metamorphism (Lee et al., 1997; Sano et al., 1999; Cherniak 


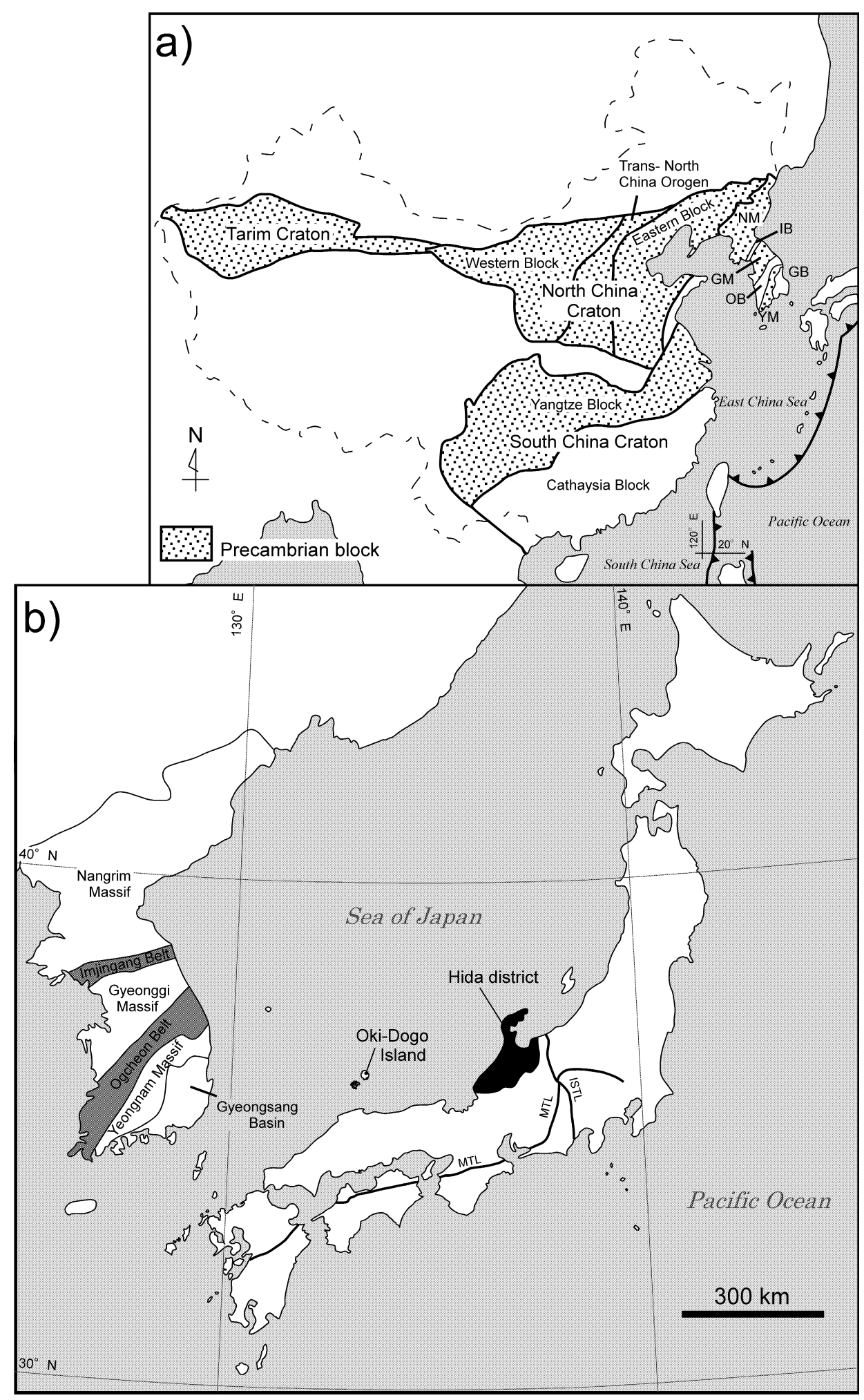

Figure 1. (a) Generalized tectonic map of East Asia (after Zhao et al., 2000). (b) Locality map of Oki-Dogo Island, Hida district, the Imjingang Belt, and the Ogcheon Belt. Abbreviations: NM, Nangrim Massif; IB, Imjingang Belt; GM, Gyeonggi Massif; OB, Ogcheon Belt; YM, Yeongnam Massif; GB, Gyeongsang Basin; ISTL, ItoigawaShizuoka Tectonic Line; MTL, Median Tectonic Line.

and Watson, 2000). As the Hida gneiss was metamorphosed under conditions of the amphibolite and lower granulite facies (Suzuki, 1977), the ages of detrital zircons in these rocks have not been significantly disturbed during metamorphism and therefore provide information on the upper age limit of the deposition and provenance of the parent rock. 


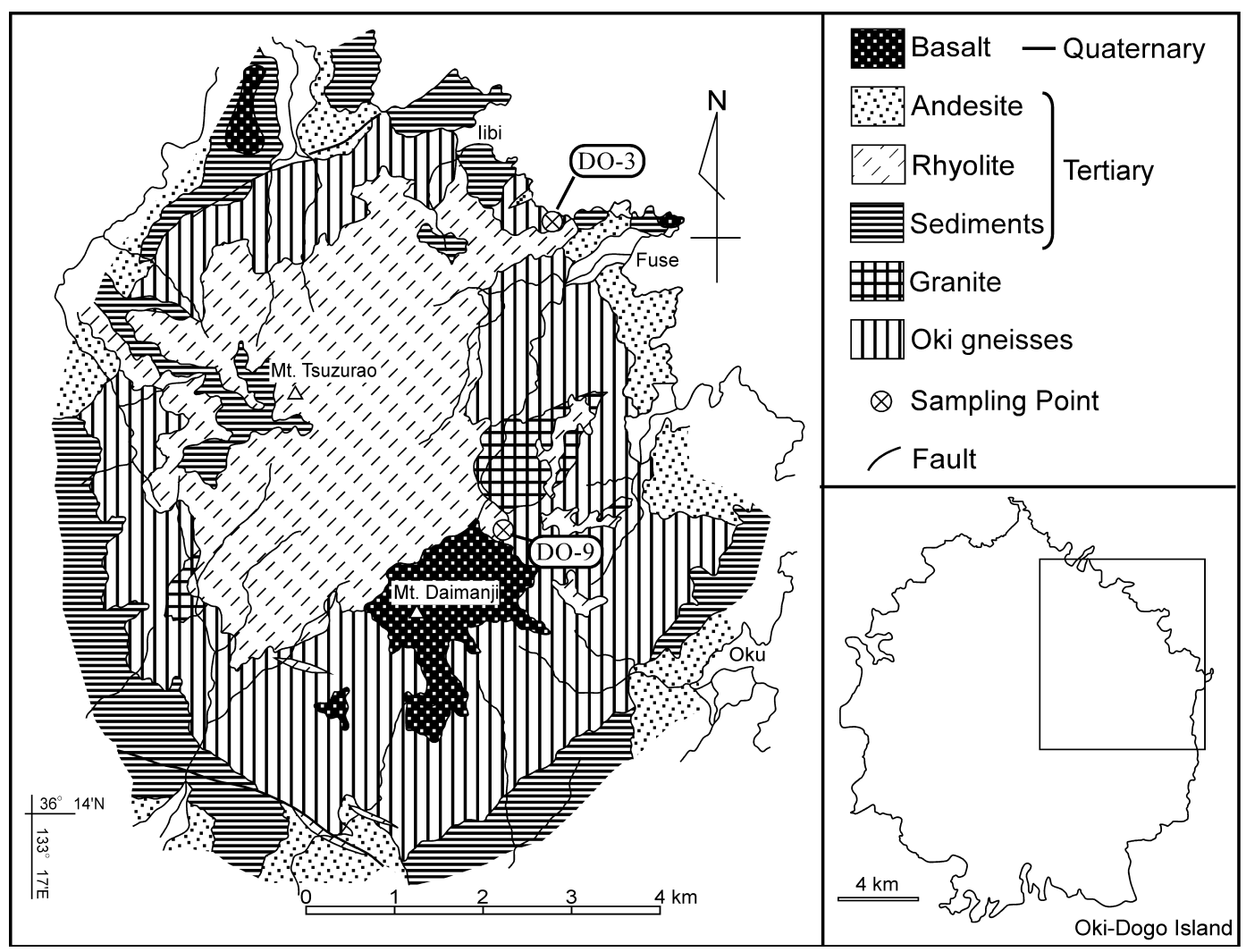

Figure 2. Geological map of Oki-Dogo Island (after Hoshino, 1979), showing sample locations.

\section{GEOLOGICAL SETTING}

Oki-Dogo Island is the largest of the Oki Islands located in the Sea of Japan. The gneisses on Oki-Dogo Island are associated with granitoids and are widely covered by Tertiary sediments and Quaternary volcanics (Fig. 2). The Oki gneisses consist mainly of pelitic to psammitic gneiss and migmatites intercalated in places with basic gneiss. The equilibrium temperature of the gneiss, estimated from $\mathrm{Fe}-\mathrm{Mg}$ partitioning coefficients between orthopyroxene and clinopyroxene in two- pyroxene amphibolite, is approximately $800{ }^{\circ} \mathrm{C}$ (Hoshino, 1979). Previously reported KAr ages of biotite are $165 \mathrm{Ma}$ and $173 \mathrm{Ma}$ (Shibata and Nozawa, 1978), while a Rb-Sr biotite age of 187 Ma has also been reported (Hayase and Ishizaka, 1967). Sm-Nd whole-rock ages have been determined for amphibolite $(1980 \pm 180 \mathrm{Ma})$ and paragneiss $(1960 \pm 820 \mathrm{Ma}$; Tanaka and Hoshino, 1987). The ages of monazites and zircons in paragneisses determined by the $\mathrm{U}$ - $\mathrm{Th}$-total $\mathrm{Pb}$ chemical isochron method (CHIME) show broad ranges in age from 250 to $1700 \mathrm{Ma}$ and 350 to $3000 \mathrm{Ma}$, respectively (Suzuki and Adachi, 1994).

\section{SAMPLES AND ANALYTICAL METHODS}

Two paragneiss samples, DO-3 and DO-9, were selected for analysis from the collection of rock specimens housed at the National Science Museum, Tokyo, Japan. The registration numbers of the samples are 130692 and 130698, respectively. DO-3 was collected from the main area of the Oki gneiss, while DO-9 was collected from an area close to a basalt vent.

Zircon grains were separated from the samples by standard crushing and heavy-liquid techniques, and then handpicked. Zircon grains from the samples and the zircon standard QGNG, with a TIMS U/Pb age of $1850 \pm 2$ Ma $(2 \sigma)$, were cemented in an epoxy resin and polished until their centers were largely exposed on a flat surface. $\mathrm{U}-\mathrm{Pb}$ dating was performed using a SHRIMP II installed at Hiroshima University, Japan. Instrumental conditions and measurement procedures are described in Sano et al. (2000). The spot size of the primary ion beam was about $20 \mu \mathrm{m}$. Both back-scattered images and cathodoluminescense images were used to select sites for SHRIMP analysis. The ${ }^{206} \mathrm{~Pb} /{ }^{238} \mathrm{U}$ ratios of the samples were calibrated using the empirical relationship described by ClaoueLong et al. (1995). In this procedure, it is essential to subtract initial $\mathrm{Pb}$ from measured $\mathrm{Pb}$ to estimate the age accurately. The measured ${ }^{206} \mathrm{~Pb} /{ }^{204} \mathrm{~Pb}$ ratio was used for the correction of initial $\mathrm{Pb}$, whose isotopic composition was assumed using a single-stage model (Compston et al., 1984). 
Table 1. ${ }^{207} \mathrm{~Pb} /{ }^{206} \mathrm{~Pb},{ }^{238} \mathrm{U} /{ }^{206} \mathrm{~Pb}$, and $\mathrm{Th} / \mathrm{U}$ ratios, $\mathrm{F}$-value, radiometric ${ }^{238} \mathrm{U} /{ }^{206} \mathrm{~Pb}^{*}$ ages, ${ }^{207} \mathrm{~Pb}^{*} / 206 \mathrm{~Pb}^{*}$ ages,

\begin{tabular}{|c|c|c|c|c|c|c|c|}
\hline Labels & ${ }^{207} \mathrm{~Pb} /{ }^{206} \mathrm{~Pb}$ & F - value ${ }^{1)}$ & ${ }^{238} \mathrm{U}^{206} \mathrm{~Pb}$ & $\mathrm{Th} / \mathrm{U}$ & $\begin{array}{c}{ }^{238} \mathrm{U}^{206} \mathrm{~Pb}^{*} \text { age }^{2)} \\
\text { (Ma) }\end{array}$ & $\begin{array}{c}{ }^{207} \mathrm{~Pb} *{ }^{206} \mathrm{~Pb}^{*} \mathrm{age}^{2} \\
(\mathrm{Ma})\end{array}$ & $\begin{array}{c}\text { 2) } \text { Disc. }^{3)} \\
(\%)\end{array}$ \\
\hline \multicolumn{8}{|c|}{ Sample DO-3 } \\
\hline DO3.01.1 & $0.1041 \pm 0.0040$ & $0.00017 \pm 0.00051$ & $3.37 \pm 0.15$ & 0.25 & $1675 \pm 66$ & $1598 \pm 64$ & $-4.8 \pm 2.7$ \\
\hline DO3.02.1 & $0.1115 \pm 0.0022$ & $0.00009 \pm 0.00031$ & $3.21 \pm 0.12$ & 0.75 & $1748 \pm 57$ & $1822 \pm 36$ & $4.1 \pm 1.5$ \\
\hline DO3.02.2 & $0.0992 \pm 0.0029$ & $0.00034 \pm 0.00038$ & $5.02 \pm 0.18$ & 0.01 & $1171 \pm 39$ & $1605 \pm 54$ & $27.0 \pm 12.8$ \\
\hline DO3.03.1 & $0.1181 \pm 0.0014$ & $0.00176 \pm 0.00077$ & $3.08 \pm 0.08$ & 0.52 & $1812 \pm 40$ & $1907 \pm 24$ & $5.0 \pm 1.3$ \\
\hline DO3.03.2 & $0.1116 \pm 0.0026$ & $<0.00001$ & $3.64 \pm 0.21$ & 0.11 & $1566 \pm 79$ & $1810 \pm 45$ & $13.5 \pm 7.6$ \\
\hline DO3.03.3 & $0.1050 \pm 0.0013$ & $0.00037 \pm 0.00011$ & $4.09 \pm 0.17$ & 0.01 & $1408 \pm 52$ & $1709 \pm 23$ & $17.6 \pm 7.0$ \\
\hline DO3.04.1 & $0.1078 \pm 0.0025$ & $0.00050 \pm 0.00030$ & $3.12 \pm 0.19$ & 0.15 & $1793 \pm 95$ & $1756 \pm 43$ & $-2.1 \pm 1.2$ \\
\hline DO3.05.1 & $0.1104 \pm 0.0019$ & $0.00006 \pm 0.00005$ & $3.30 \pm 0.05$ & 0.09 & $1705 \pm 23$ & $1805 \pm 31$ & $5.5 \pm 1.2$ \\
\hline DO3.07.1 & $0.1761 \pm 0.0067$ & $<0.00001$ & $1.80 \pm 0.06$ & 0.27 & $2853 \pm 81$ & $2617 \pm 62$ & $-9.0 \pm 3.3$ \\
\hline DO3.08.1 & $0.1180 \pm 0.0010$ & $0.00028 \pm 0.00026$ & $2.78 \pm 0.06$ & 0.16 & $1977 \pm 39$ & $1923 \pm 16$ & $-2.9 \pm 0.6$ \\
\hline DO3.09.1 & $0.1130 \pm 0.0047$ & $0.00033 \pm 0.00028$ & $3.13 \pm 0.11$ & 0.13 & $1787 \pm 57$ & $1845 \pm 74$ & $3.2 \pm 1.6$ \\
\hline DO3.11.1 & $0.1182 \pm 0.0015$ & $0.00019 \pm 0.00015$ & $3.09 \pm 0.05$ & 0.22 & $1805 \pm 28$ & $1926 \pm 23$ & $6.3 \pm 1.2$ \\
\hline DO3.12.1 & $0.1130 \pm 0.0024$ & $<0.00001$ & $2.97 \pm 0.05$ & 0.17 & $1868 \pm 25$ & $1848 \pm 38$ & $-1.1 \pm 0.3$ \\
\hline DO3.12.2 & $0.1120 \pm 0.0043$ & $0.00040 \pm 0.00017$ & $4.66 \pm 0.25$ & 0.01 & $1253 \pm 62$ & $1738 \pm 62$ & $27.9 \pm 17.0$ \\
\hline DO3.13.1 & $0.1205 \pm 0.0035$ & $<0.00001$ & $3.62 \pm 0.17$ & 0.19 & $1574 \pm 65$ & $1963 \pm 53$ & $19.8 \pm 9.8$ \\
\hline DO3.14.1 & $0.1112 \pm 0.0020$ & $0.00030 \pm 0.00012$ & $2.91 \pm 0.04$ & 0.48 & $1905 \pm 25$ & $1814 \pm 33$ & $-5.0 \pm 1.1$ \\
\hline DO3.15.1 & $0.1126 \pm 0.0072$ & $0.00036 \pm 0.00024$ & $3.41 \pm 0.19$ & 0.35 & $1656 \pm 82$ & $1737 \pm 109$ & $4.6 \pm 3.7$ \\
\hline DO3.16.1 & $0.1123 \pm 0.0011$ & $0.00001 \pm 0.00055$ & $3.43 \pm 0.02$ & 0.95 & $1648 \pm 10$ & $1837 \pm 19$ & $10.3 \pm 1.2$ \\
\hline DO3.17.1 & $0.1114 \pm 0.0010$ & $0.00020 \pm 0.00009$ & $3.16 \pm 0.03$ & 0.38 & $1773 \pm 14$ & $1820 \pm 17$ & $2.6 \pm 0.3$ \\
\hline DO3.17.2 & $0.1092 \pm 0.0030$ & $0.00056 \pm 0.00024$ & $3.66 \pm 0.09$ & 0.01 & $1555 \pm 35$ & $1779 \pm 49$ & $12.6 \pm 4.5$ \\
\hline DO3.18.1 & $0.1151 \pm 0.0025$ & $0.00000 \pm 0.00003$ & $3.12 \pm 0.08$ & 0.43 & $1792 \pm 38$ & $1881 \pm 39$ & $4.7 \pm 1.4$ \\
\hline DO3.19.1 & $0.1068 \pm 0.0025$ & $<0.00001$ & $3.28 \pm 0.12$ & 0.11 & $1716 \pm 53$ & $1745 \pm 42$ & $1.7 \pm 0.7$ \\
\hline DO3.19.2 & $0.0531 \pm 0.0010$ & $0.00191 \pm 0.00182$ & $26.82 \pm 0.35$ & 0.02 & $236 \pm 3$ & $263 \pm 83$ & $10.5 \pm 33.0$ \\
\hline DO3.20.1 & $0.1123 \pm 0.0056$ & $<0.00001$ & $3.85 \pm 0.23$ & 0.19 & $1490 \pm 80$ & $1838 \pm 88$ & $18.9 \pm 13.6$ \\
\hline DO3.20.2 & $0.1060 \pm 0.0012$ & $0.00004 \pm 0.00006$ & $4.29 \pm 0.10$ & 0.02 & $1351 \pm 28$ & $1731 \pm 20$ & $21.9 \pm 5.3$ \\
\hline DO3.21.1 & $0.1141 \pm 0.0011$ & $<0.00001$ & $2.81 \pm 0.02$ & 0.13 & $1964 \pm 14$ & $1866 \pm 17$ & $-5.2 \pm 0.6$ \\
\hline DO3.22.1 & $0.1298 \pm 0.0036$ & $0.00064 \pm 0.00020$ & $3.68 \pm 0.07$ & 0.14 & $1548 \pm 25$ & $2088 \pm 48$ & $25.9 \pm 7.3$ \\
\hline DO3.22.2 & $0.1094 \pm 0.0040$ & $0.00025 \pm 0.00021$ & $4.07 \pm 0.14$ & 0.01 & $1415 \pm 44$ & $1877 \pm 61$ & $24.6 \pm 11.1$ \\
\hline DO3.23.1 & $0.1137 \pm 0.0038$ & $0.00058 \pm 0.00032$ & $3.18 \pm 0.05$ & 0.16 & $1761 \pm 27$ & $1874 \pm 67$ & $6.0 \pm 2.4$ \\
\hline DO3.24.1 & $0.1087 \pm 0.0007$ & $0.00019 \pm 0.00005$ & $3.09 \pm 0.03$ & 0.31 & $1808 \pm 17$ & $1778 \pm 10$ & $-1.7 \pm 0.2$ \\
\hline DO3.24.2 & $0.1076 \pm 0.0020$ & $0.00022 \pm 0.00018$ & $3.01 \pm 0.07$ & 0.30 & $1851 \pm 39$ & $1722 \pm 17$ & $-7.5 \pm 1.7$ \\
\hline DO3.24.3 & $0.1063 \pm 0.0038$ & $0.00005 \pm 0.00002$ & $5.01 \pm 0.11$ & 0.01 & $1174 \pm 23$ & $1736 \pm 64$ & $32.4 \pm 13.5$ \\
\hline DO3.25.1 & $0.1079 \pm 0.0017$ & $<0.00001$ & $5.16 \pm 0.18$ & 0.01 & $1143 \pm 37$ & $1764 \pm 28$ & $35.2 \pm 12.6$ \\
\hline DO3.26.1 & $0.1133 \pm 0.0011$ & $0.00009 \pm 0.00016$ & $3.20 \pm 0.05$ & 0.18 & $1754 \pm 23$ & $1851 \pm 18$ & $5.2 \pm 0.9$ \\
\hline DO3.27.1 & $0.1518 \pm 0.0039$ & $<0.00001$ & $2.13 \pm 0.06$ & 0.84 & $2481 \pm 56$ & $2366 \pm 44$ & $-4.9 \pm 1.4$ \\
\hline DO3.28.1 & $0.1356 \pm 0.0010$ & $0.00033 \pm 0.00024$ & $2.56 \pm 0.06$ & 0.34 & $2124 \pm 43$ & $2169 \pm 13$ & $2.1 \pm 0.4$ \\
\hline DO3.28.2 & $0.1156 \pm 0.0026$ & $0.00056 \pm 0.00023$ & $3.12 \pm 0.07$ & 0.11 & $1790 \pm 34$ & $1933 \pm 32$ & $7.4 \pm 1.9$ \\
\hline DO3.29.1 & $0.1155 \pm 0.0010$ & $0.00006 \pm 0.00029$ & $3.36 \pm 0.07$ & 0.20 & $1680 \pm 30$ & $1887 \pm 15$ & $11.0 \pm 2.2$ \\
\hline DO3.30.1 & $0.1049 \pm 0.0038$ & $0.00029 \pm 0.00029$ & $6.40 \pm 0.20$ & 0.04 & $935 \pm 27$ & $1725 \pm 63$ & $45.8 \pm 21.3$ \\
\hline
\end{tabular}


and degree of discordance (Disc.) of zircons in samples from Oki-Dogo Island.

\begin{tabular}{|c|c|c|c|c|c|c|c|}
\hline Labels & ${ }^{207} \mathrm{~Pb} /{ }^{206} \mathrm{~Pb}$ & F - value ${ }^{1)}$ & ${ }^{238} \mathrm{U}^{206} \mathrm{~Pb}$ & $\mathrm{Th} / \mathrm{U}$ & $\begin{array}{c}{ }^{238} \mathrm{U}^{206} \mathrm{~Pb}^{*} \text { age }^{2)} \\
\text { (Ma) }\end{array}$ & $\begin{array}{c}{ }^{207} \mathrm{~Pb}^{*}{ }^{206} \mathrm{~Pb}^{*} \text { age } \\
(\mathrm{Ma})\end{array}$ & $\begin{array}{l}\text { 2) } \text { Disc. }^{3)} \\
(\%)\end{array}$ \\
\hline DO3.30.2 & $0.1124 \pm 0.0071$ & $0.00225 \pm 0.00117$ & $3.95 \pm 0.11$ & 0.25 & $1450 \pm 35$ & $1810 \pm 114$ & $19.9 \pm 13.3$ \\
\hline DO3.30.3 & $0.1073 \pm 0.0028$ & $0.00065 \pm 0.00036$ & $5.30 \pm 0.11$ & 0.04 & $1115 \pm 22$ & $1745 \pm 48$ & $36.1 \pm 12.1$ \\
\hline DO3.31.1 & $0.1602 \pm 0.0008$ & $0.00087 \pm 0.00045$ & $2.44 \pm 0.06$ & 0.56 & $2209 \pm 43$ & $2451 \pm 10$ & $9.9 \pm 2.0$ \\
\hline DO3.31.2 & $0.1092 \pm 0.0040$ & $0.00010 \pm 0.00005$ & $4.18 \pm 0.12$ & 0.06 & $1382 \pm 37$ & $1785 \pm 66$ & $22.6 \pm 10.3$ \\
\hline DO3.32.1 & $0.1575 \pm 0.0014$ & $0.00030 \pm 0.00039$ & $2.23 \pm 0.02$ & 0.45 & $2387 \pm 20$ & $2427 \pm 16$ & $1.6 \pm 0.2$ \\
\hline DO3.32.2 & $0.1159 \pm 0.0025$ & $0.00059 \pm 0.00022$ & $3.32 \pm 0.13$ & 0.12 & $1696 \pm 58$ & $1887 \pm 39$ & $10.1 \pm 4.0$ \\
\hline DO3.33.1 & $0.1104 \pm 0.0041$ & $<0.00001$ & $6.97 \pm 0.15$ & 0.05 & $865 \pm 17$ & $1807 \pm 66$ & $52.1 \pm 21.8$ \\
\hline DO3.33.2 & $0.1005 \pm 0.0021$ & $0.00009 \pm 0.00002$ & $3.14 \pm 0.11$ & 0.01 & $1783 \pm 57$ & $1631 \pm 38$ & $-9.3 \pm 3.7$ \\
\hline DO3.34.1 & $0.1132 \pm 0.0008$ & $0.00070 \pm 0.00077$ & $3.30 \pm 0.09$ & 0.55 & $1704 \pm 42$ & $1843 \pm 17$ & $7.6 \pm 2.0$ \\
\hline DO3.35.1 & $0.1113 \pm 0.0009$ & $0.00022 \pm 0.00011$ & $3.18 \pm 0.13$ & 0.44 & $1764 \pm 62$ & $1818 \pm 15$ & $3.0 \pm 1.1$ \\
\hline DO3.36.1 & $0.1107 \pm 0.0027$ & $<0.00001$ & $4.08 \pm 0.09$ & 0.33 & $1413 \pm 28$ & $1811 \pm 46$ & $22.0 \pm 7.0$ \\
\hline DO3.37.1 & $0.1157 \pm 0.0033$ & $<0.00001$ & $3.34 \pm 0.12$ & 0.13 & $1689 \pm 53$ & $1891 \pm 52$ & $10.7 \pm 4.4$ \\
\hline DO3.38.1 & $0.1136 \pm 0.0014$ & $<0.00001$ & $3.49 \pm 0.07$ & 0.55 & $1625 \pm 28$ & $1857 \pm 22$ & $12.5 \pm 2.6$ \\
\hline DO3.39.1 & $0.1124 \pm 0.0012$ & $0.00014 \pm 0.00031$ & $3.35 \pm 0.08$ & 0.16 & $1684 \pm 37$ & $1838 \pm 20$ & $8.4 \pm 2.1$ \\
\hline DO3.40.1 & $0.1124 \pm 0.0015$ & $<0.00001$ & $3.27 \pm 0.05$ & 0.41 & $1719 \pm 25$ & $1839 \pm 26$ & $6.5 \pm 1.3$ \\
\hline DO3.41.1 & $0.1097 \pm 0.0013$ & $0.00075 \pm 0.00026$ & $4.04 \pm 0.06$ & 0.27 & $1425 \pm 18$ & $1785 \pm 22$ & $20.2 \pm 3.5$ \\
\hline DO3.42.1 & $0.1258 \pm 0.0029$ & $0.00046 \pm 0.00031$ & $3.00 \pm 0.10$ & 0.14 & $1851 \pm 55$ & $2036 \pm 41$ & $9.1 \pm 3.3$ \\
\hline DO3.43.1 & $0.1130 \pm 0.0024$ & $0.00068 \pm 0.00013$ & $4.05 \pm 0.07$ & 0.01 & $1422 \pm 22$ & $1840 \pm 38$ & $22.7 \pm 5.8$ \\
\hline DO3.44.1 & $0.1123 \pm 0.0062$ & $<0.00001$ & $3.89 \pm 0.13$ & 0.12 & $1475 \pm 45$ & $1837 \pm 97$ & $19.7 \pm 12.0$ \\
\hline \multicolumn{8}{|c|}{ Sample DO-9 } \\
\hline DO9.01.1 & $0.1487 \pm 0.0021$ & $0.00005 \pm 0.00051$ & $2.40 \pm 0.09$ & 0.51 & $2241 \pm 69$ & $2330 \pm 25$ & $3.8 \pm 1.2$ \\
\hline DO9.02.1 & $0.1249 \pm 0.0022$ & $<0.00001$ & $3.14 \pm 0.07$ & 0.30 & $1781 \pm 33$ & $2028 \pm 31$ & $12.2 \pm 2.9$ \\
\hline DO9.03.1 & $0.1177 \pm 0.0025$ & $<0.00001$ & $2.69 \pm 0.08$ & 0.44 & $2036 \pm 49$ & $1922 \pm 38$ & $-5.9 \pm 1.8$ \\
\hline DO9.04.1 & $0.1378 \pm 0.0017$ & $0.00011 \pm 0.00016$ & $2.57 \pm 0.07$ & 0.75 & $2121 \pm 46$ & $2199 \pm 22$ & $3.6 \pm 0.8$ \\
\hline DO9.05.1 & $0.1361 \pm 0.0032$ & $0.00008 \pm 0.00018$ & $2.23 \pm 0.09$ & 0.68 & $2385 \pm 77$ & $2177 \pm 40$ & $-9.6 \pm 3.6$ \\
\hline D09.06.1 & $0.1241 \pm 0.0013$ & $0.00002 \pm 0.00011$ & $2.86 \pm 0.08$ & 0.24 & $1934 \pm 48$ & $2015 \pm 18$ & $4.0 \pm 1.1$ \\
\hline DO9.07.1 & $0.0969 \pm 0.0029$ & $0.00357 \pm 0.00220$ & $13.73 \pm 0.39$ & 0.03 & $452 \pm 12$ & $1509 \pm 69$ & $70.1 \pm 37.3$ \\
\hline DO9.08.1 & $0.1395 \pm 0.0051$ & $0.00086 \pm 0.00080$ & $2.36 \pm 0.10$ & 0.53 & $2272 \pm 82$ & $2212 \pm 63$ & $-2.7 \pm 1.2$ \\
\hline DO9.09.1 & $0.1325 \pm 0.0065$ & $0.00004 \pm 0.00006$ & $2.38 \pm 0.08$ & 0.44 & $2261 \pm 68$ & $2131 \pm 83$ & $-6.1 \pm 3.0$ \\
\hline DO9.10.1 & $0.1395 \pm 0.0035$ & $0.00019 \pm 0.00126$ & $2.35 \pm 0.10$ & 0.61 & $2287 \pm 79$ & $2220 \pm 45$ & $-3.0 \pm 1.2$ \\
\hline DO9.11.1 & $0.1208 \pm 0.0024$ & $0.00014 \pm 0.00020$ & $3.58 \pm 0.12$ & 0.21 & $1588 \pm 47$ & $1966 \pm 35$ & $19.3 \pm 6.6$ \\
\hline DO9.12.1 & $0.0732 \pm 0.0020$ & $0.00047 \pm 0.00034$ & $24.05 \pm 0.65$ & 0.01 & $262 \pm 7$ & $1010 \pm 55$ & $74.0 \pm 44.9$ \\
\hline DO9.13.1 & $0.1438 \pm 0.0056$ & $0.00100 \pm 0.00067$ & $2.22 \pm 0.17$ & 0.74 & $2396 \pm 152$ & $2265 \pm 66$ & $-5.8 \pm 4.0$ \\
\hline DO9.14.1 & $0.1323 \pm 0.0020$ & $0.00002 \pm 0.00005$ & $2.92 \pm 0.08$ & 0.45 & $1897 \pm 47$ & $2129 \pm 26$ & $10.9 \pm 3.0$ \\
\hline DO9.15.1 & $0.1326 \pm 0.0027$ & $0.00141 \pm 0.00126$ & $2.95 \pm 0.15$ & 0.44 & $1878 \pm 84$ & $2118 \pm 39$ & $11.4 \pm 5.5$ \\
\hline DO9.16.1 & $0.1458 \pm 0.0015$ & $0.00013 \pm 0.00015$ & $2.45 \pm 0.08$ & 0.50 & $2204 \pm 59$ & $2296 \pm 18$ & $4.0 \pm 1.1$ \\
\hline DO9.17.1 & $0.1247 \pm 0.0021$ & $<0.00001$ & $3.03 \pm 0.11$ & 0.38 & $1837 \pm 58$ & $2024 \pm 30$ & $9.2 \pm 3.2$ \\
\hline DO9.18.1 & $0.1480 \pm 0.0036$ & $0.00098 \pm 0.00098$ & $3.06 \pm 0.14$ & 0.88 & $1819 \pm 72$ & $2314 \pm 42$ & $21.4 \pm 9.3$ \\
\hline DO9.19.1 & $0.1365 \pm 0.0037$ & $0.00020 \pm 0.00032$ & $2.43 \pm 0.07$ & 0.27 & $2224 \pm 56$ & $2181 \pm 46$ & $-2.0 \pm 0.7$ \\
\hline
\end{tabular}


Table 1. (Continued)

\begin{tabular}{lllccccc}
\hline Labels & ${ }^{207} \mathrm{~Pb}{ }^{206} \mathrm{~Pb}$ & $\mathrm{~F}$ - value ${ }^{1)}$ & ${ }^{238} \mathrm{U}^{206} \mathrm{~Pb}$ & $\mathrm{Th} / \mathrm{U}$ & $\begin{array}{c}{ }^{238} \mathrm{U}^{206} \mathrm{~Pb}^{*} \mathrm{age}^{2)} \\
(\mathrm{Ma})\end{array}$ & $\begin{array}{c}{ }^{207} \mathrm{~Pb}^{*}{ }^{206} \mathrm{~Pb}^{*} \mathrm{age}^{2)} \\
(\mathrm{Ma})\end{array}$ & $\begin{array}{c}\mathrm{Disc}{ }^{3)} \\
(\%)\end{array}$ \\
\hline DO9.20.1 & $0.1165 \pm 0.0014$ & $<0.00001$ & $3.47 \pm 0.08$ & 0.22 & $1634 \pm 32$ & $1904 \pm 22$ & $14.2 \pm 3.3$ \\
DO9.21.1 & $0.1300 \pm 0.0070$ & $0.00257 \pm 0.00227$ & $2.96 \pm 0.16$ & 0.75 & $1871 \pm 88$ & $2071 \pm 97$ & $9.7 \pm 6.4$ \\
DO9.22.1 & $0.1300 \pm 0.0046$ & $0.00062 \pm 0.00059$ & $2.91 \pm 0.11$ & 0.09 & $1902 \pm 61$ & $2091 \pm 62$ & $9.0 \pm 4.0$ \\
DO9.23.1 & $0.1285 \pm 0.0021$ & $0.00019 \pm 0.00014$ & $2.98 \pm 0.06$ & 0.23 & $1866 \pm 30$ & $2076 \pm 29$ & $10.1 \pm 2.2$ \\
D09.24.1 & $0.1300 \pm 0.0013$ & $0.00011 \pm 0.00027$ & $3.26 \pm 0.08$ & 0.95 & $1725 \pm 39$ & $2096 \pm 18$ & $17.7 \pm 4.3$ \\
D09.27.1 & $0.1218 \pm 0.0016$ & $<0.00001$ & $3.46 \pm 0.09$ & 0.17 & $1636 \pm 36$ & $1983 \pm 24$ & $17.5 \pm 4.4$ \\
\hline
\end{tabular}

${ }^{1)}$ The $\mathrm{F}$-value is defined as 'initial ${ }^{206} \mathrm{~Pb} /$ total ${ }^{206} \mathrm{~Pb}$ '.

${ }^{2)}{ }^{206} \mathrm{~Pb}^{*}$ and ${ }^{207} \mathrm{~Pb}^{*}$ mean radiometric ${ }^{206} \mathrm{~Pb}$ and ${ }^{207} \mathrm{~Pb}$, respectively.

${ }^{3)}$ The degree of discordance for an analyzed area represents the chronological difference between the two ages determined by the $\mathrm{Pb}-\mathrm{Pb}$ and $\mathrm{U}-\mathrm{Pb}$ methods, and is defined as $\left[1-\left({ }^{238} \mathrm{U} /{ }^{206} \mathrm{~Pb}^{*}\right.\right.$ age $) /\left({ }^{207} \mathrm{~Pb}^{*} / 206 \mathrm{~Pb}^{*}\right.$ age $\left.)\right] \times 100$ (\%) (e.g., Biao et al., 1996).

\section{RESULTS}

Table 1 lists zircon data in terms of ${ }^{207} \mathrm{~Pb} /{ }^{206} \mathrm{~Pb},{ }^{238} \mathrm{U} /{ }^{206} \mathrm{~Pb}$, and $\mathrm{Th} / \mathrm{U}$ ratios; $\mathrm{F}$ value (initial ${ }^{206} \mathrm{~Pb} /$ total ${ }^{206} \mathrm{~Pb}$ ); radiometric ${ }^{238} \mathrm{U} /{ }^{206} \mathrm{~Pb}^{*}$ ages; ${ }^{207} \mathrm{~Pb}^{*} /{ }^{206} \mathrm{~Pb}$ ages; and degree of discordance. The degree of discordance for an analyzed area indicates the chronological difference between the two ages determined by the $\mathrm{Pb}-\mathrm{Pb}$ and $\mathrm{U}-\mathrm{Pb}$ methods, and is defined as $\left\{1-\left({ }^{238} \mathrm{U} /{ }^{206} \mathrm{~Pb}^{*}\right.\right.$ age $) /\left({ }^{207} \mathrm{~Pb}^{*} /{ }^{206} \mathrm{~Pb}^{*}\right.$ age $\left.)\right\}$ $\times 100(\%)$ (e.g., Biao et al., 1996). The magnitude of discordance indicates the degree of disturbance of the $\mathrm{U}-\mathrm{Pb}$ system within a sample. Subnumbers in Table 1 such as DO3.02.1 and DO3.02.2 indicate different pit positions within a grain, as shown in Figure 3.

Figure 4 shows Tera-Wasserberg concordia diagrams for the two gneiss samples. The ages of zircons in paragneiss sample DO-3 cluster in the range 1600 to $2000 \mathrm{Ma}$ (Fig. 4a). This cluster includes a number of discordant points with younger ages. The oldest zircon plotted on the concordia curve is $2600 \mathrm{Ma}$, while the youngest is $236 \pm$ $3 \mathrm{Ma}$, obtained from a zircon rim. All zircon age data for DO-9, except for two points, plot in a cluster ranging from 1900 to $2400 \mathrm{Ma}$ (Fig. 4b). Data points in this cluster are closer to the concordia curve than those for DO-3. All data points for samples DO-3 and DO-9 fall within a triangular area on the concordia diagram with apexes of approximately $240 \mathrm{Ma}, 1600 \mathrm{Ma}$, and $2800 \mathrm{Ma}$ (Fig. 4).

Figure 5 shows three kinds of probability distribution diagrams for samples $\mathrm{DO}-3$ and $\mathrm{DO}-9$ : $\mathrm{U}-\mathrm{Pb}$ age, $\mathrm{Pb}-\mathrm{Pb}$ age, and $\mathrm{Pb}-\mathrm{Pb}$ age $(-10<\operatorname{Disc}(\%)<10)$. 'Disc $(\%)$ ' is the degree of discordance for an analyzed area and indicates the chronological difference between the two ages determined by the $\mathrm{Pb}-\mathrm{Pb}$ and $\mathrm{U}-\mathrm{Pb}$ methods; this is defined as $\left\{1-\left({ }^{238} \mathrm{U} /{ }^{206} \mathrm{~Pb}^{*}\right.\right.$ age $) /\left({ }^{207} \mathrm{~Pb}^{*} /{ }^{206} \mathrm{~Pb}^{*}\right.$ age $\left.)\right\} \times 100$ (\%) (e.g., Biao et al., 1996). All analytical data were used for the distribution diagrams of both the $\mathrm{U}-\mathrm{Pb}$ and $\mathrm{Pb}-\mathrm{Pb}$

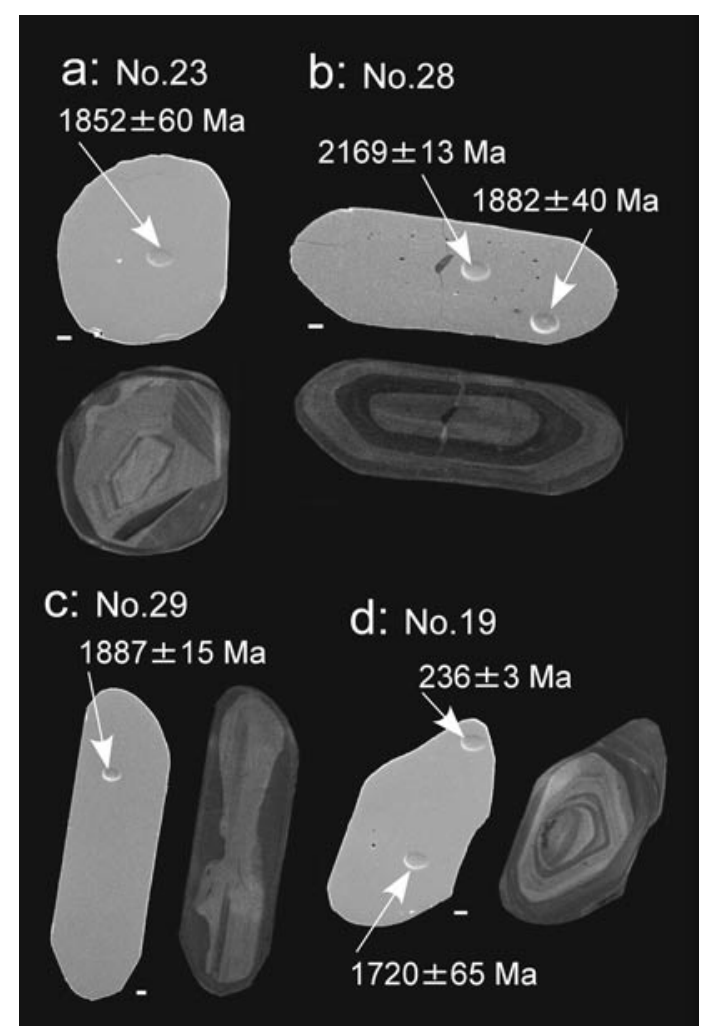

Figure 3. Secondary electron images (SEIs; after analysis) and cathodoluminescense images of zircon grains from sample DO-3. Pits on SEIs are analytical sites for SHRIMP dating. Scale bars are $10 \mu \mathrm{m}$ across.

ages. In addition to uncertainty in the discordant data, error margins for $\mathrm{U}-\mathrm{Pb}$ and $\mathrm{Pb}-\mathrm{Pb}$ ages are large for older and younger ages, respectively. In contrast, the plot of $\mathrm{Pb}-\mathrm{Pb}$ ages $(-10<$ Disc $(\%)<10)$ provides the most probable age distribution for the samples, as the data are on or near the concordia line. 

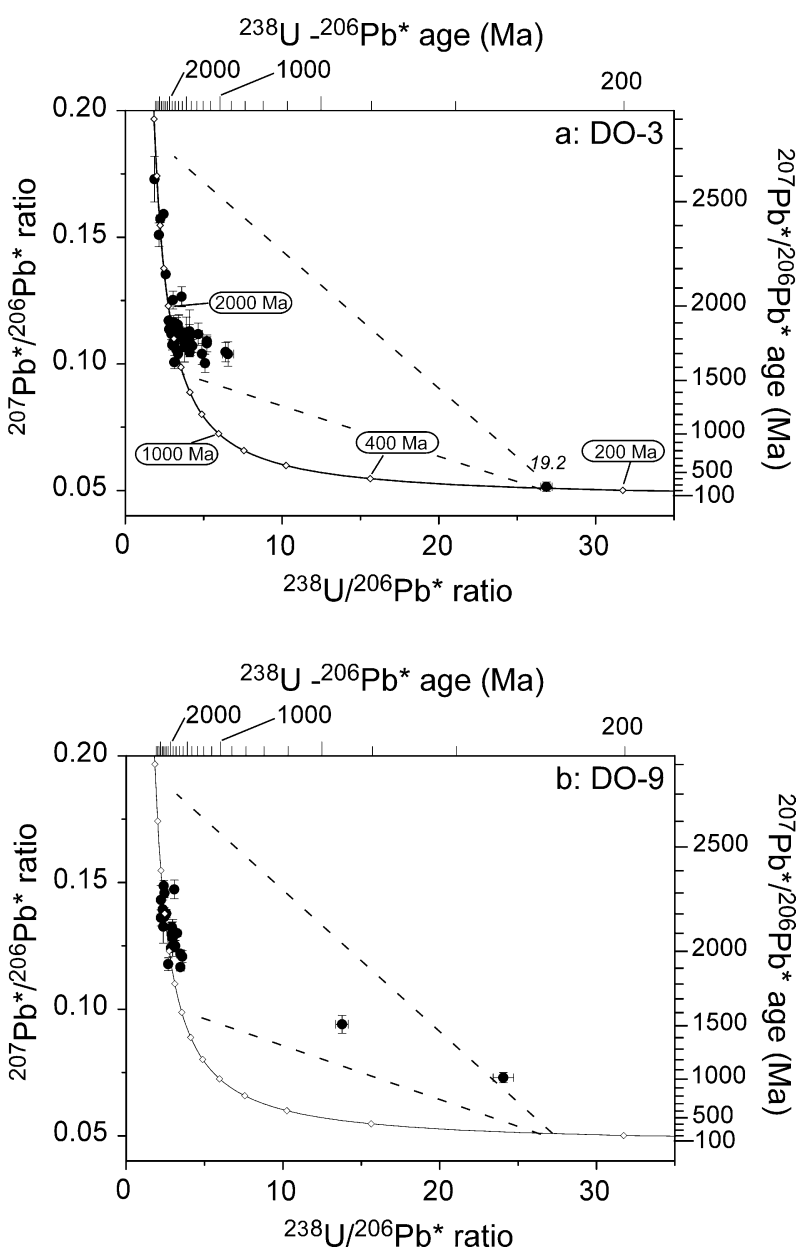

Figure 4. Tera-Wasserberg $\mathrm{U}-\mathrm{Pb}$ concordia diagrams for zircons from the paragneiss samples DO-3 (a) and DO-9 (b). ${ }^{207} \mathrm{~Pb}^{*}$ and ${ }^{206} \mathrm{~Pb}^{*}$ indicate radiometric ${ }^{207} \mathrm{~Pb}$ and ${ }^{206} \mathrm{~Pb}$, respectively. Solid curves are concordia curves.

\section{DISCUSSION}

At first glance, the apparent ${ }^{238} \mathrm{U}^{-206} \mathrm{~Pb}^{*}$ age spectrum of zircons from the Oki gneiss analyzed in this study (solid lines in Fig. 5) corresponds with the CHIME zircon ages (Suzuki and Adachi, 1994) in that both data sets contain a large number of old ages (ca. 1250, 1700, 2000, and 3000 Ma) and a smaller number of young ages (ca. $350 \mathrm{Ma}$ ). However, when the data are plotted on Tera-Wasserberg concordia diagrams, it turns out that most of the younger ages are derived from discordant data. Discordant data on the concordia diagram trend toward 300 to $200 \mathrm{Ma}$. Most of the concordant data range from 1600 to $2000 \mathrm{Ma}$ for DO-3 gneiss and from 1900 to $2400 \mathrm{Ma}$ for DO-9 gneiss, with only one rim analysis yielding a young concordant age of $236 \pm 3 \mathrm{Ma}$ in sample DO- 3 . This $236 \mathrm{Ma}$ age is consistent with a CHIME monazite age that is interpreted to represent the age of metamorphism (Suzuki and Adachi, 1994). Concordant ages for sample DO-3 have a

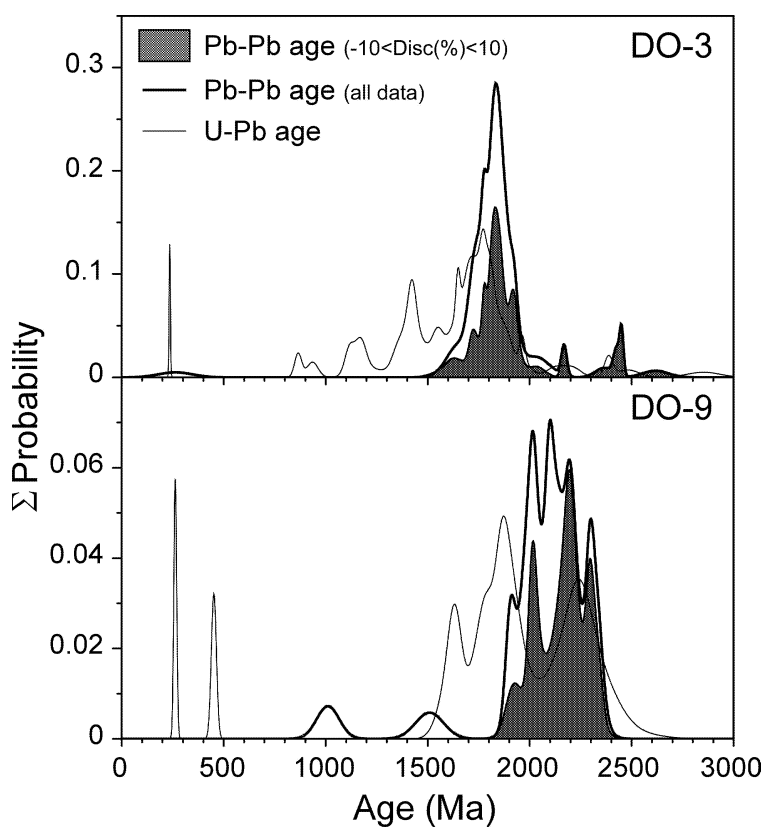

Figure 5. Probability distribution diagrams of zircon ages from samples DO-3 (a) and DO-9 (b). Distribution curves for $\mathrm{U} / \mathrm{Pb}$ age, $\mathrm{Pb} / \mathrm{Pb}$ age, and $\mathrm{Pb}-\mathrm{Pb}$ age $(-10<$ Disc $(\%)<10)$ are represented by fine lines, thick lines, and shaded areas, respectively. The $\mathrm{Pb}-\mathrm{Pb}$ age $(-10<$ Disc $(\%)<10)$ data represent the most probable age distribution for the samples, as the data lie on or near the concordia line.

major peak at 1800 to $1900 \mathrm{Ma}$ and small peaks at 2200 Ma, $2400 \mathrm{Ma}$, and $2600 \mathrm{Ma}$ (shaded area in Fig. 5a).

Late Archean basement rocks occur widely across the North China Craton, and are mainly 2500 to $2600 \mathrm{Ma}$ in age (Zhao et al., 2001). Although ages of $2400 \mathrm{Ma}$ and 1800 to $2200 \mathrm{Ma}$ are relatively rare in the North China Craton, they are more common in the Trans-North China Orogen (Fig. 1a). Zircon ages of 1600 to $2200 \mathrm{Ma}$ are common in both the Gyeonggi and Yeongnam Massifs, Korea (e.g., Kwon and Jeong, 1990; Truek and Kim, 1996; Kim et al., 1999; Cheong et al., 2000; Lee et al., 2000; Sagong et al., 2003). Given the above age data, it appears that detrital zircons in sample DO-3 were mainly derived from Korean basement rocks, with a minor contribution from the North China Craton. In contrast, detrital zircons in sample DO-9 show a different age distribution, with a continuous distribution from 1900 to $2300 \mathrm{Ma}$ (shaded area in Fig. 5b) and four peaks at 1900, 2000, 2200, and $2400 \mathrm{Ma}$. Although detrital zircons in sample DO-9 clearly show older ages than those in DO-3, the absence of Archean zircons suggests that the major provenance of the zircons in DO-9 is also the Korean Peninsula.

Sano et al. (2000) measured the $\mathrm{U}-\mathrm{Pb}$ and $\mathrm{Pb}-\mathrm{Pb}$ ages of zircons in Hida gneiss from the Amo area, and found that their concordant $\mathrm{U}-\mathrm{Pb}$ ages are mostly younger 
than $400 \mathrm{Ma}$. The Oki gneiss was previously considered to be an equivalent of the Hida gneiss, but the age distributions of zircons in the two gneisses are clearly different. The Tera-Wasserberg concordia diagrams shown in Figure 4 demonstrate that the lower intercepts of discordant data are around 200 to $300 \mathrm{Ma}$. If deposition of the parent material of the Oki gneiss occurred after $350 \mathrm{Ma}$, we would expect concordant core ages younger than 400 Ma. It is unrealistic to expect that concordant core ages in the Oki gneiss were restricted to ages in excess of 1600 Ma because igneous activity occurred across vast areas of East Asia subsequent to 350 Ma (e.g., Wang, 1986; Lee, 1987).

Sm-Nd whole-rock ages for Oki gneiss are $1980 \pm$ $180 \mathrm{Ma}$ for amphibolite and $1960 \pm 820 \mathrm{Ma}$ for paragneiss (Tanaka and Hoshino, 1987), which are similar to the average zircon ages for the Oki gneiss. If deposition was younger than $350 \mathrm{Ma}$, the drainage system would only have supplied detrital minerals to the paragneiss from older geological terranes, without any contribution from younger igneous rocks. As amphibolite was originally an igneous rock, it is reasonable to conclude that the whole-rock Sm-Nd age of $1980 \pm 180 \mathrm{Ma}$ indicates the crystallization age of the parent rock. Tanaka and Hoshino (1987) also concluded that the whole-rock age of the paragneiss represents the timing of source rock formation or the depositional age, as the CHUR model age for the paragneiss at Oki is 2.2 to $2.3 \mathrm{Ga}$. Model ages for the main part of the Hida gneiss are 1.0 to $1.5 \mathrm{Ga}$ (Asano et al., 1990). Compiled Sm-Nd isotopic data for Korean basement rocks indicate a model age for the Gyeonggi Massif mainly in the range 2.5 to $3.0 \mathrm{Ga}$, with and some young (ca. $1.8 \mathrm{Ga}$ ) and old (older than $3.0 \mathrm{Ga}$ ) ages. Ages for the Yeongnam Massif show three clusters at around 1.5 Ga, 2.0 to $2.5 \mathrm{Ga}$, and $2.5 \mathrm{Ga}$ (Cheong et al., 2000). In terms of $\mathrm{Sm}-\mathrm{Nd}$ isotopic data from Korean basement rocks, the Oki gneiss data are consistent with the 2.0 to 2.5 $\mathrm{Ga}$ age cluster of the Yeongnam Massif. This indicates that the parent rocks of the Oki gneiss were related to the Yeongnam Massif rather than gneiss in the Hida area. Considering the relatively old ages of zircons in gneiss and old whole-rock age of associated amphibolite, it is reasonable to conclude that the parent rock of paragneiss on Oki-Dogo Island was deposited during the Proterozoic (ca. $1600 \mathrm{Ma}$ ) rather than during the Phanerozoic. Furthermore, it is possible that the Oki gneiss was once part of the Yeongnam Massif.

A number of $\mathrm{U}-\mathrm{Pb}$ zircon ages have been reported for Precambrian rocks from the Japanese Islands. SHRIMP $\mathrm{U}-\mathrm{Pb}$ and $\mathrm{Pb}-\mathrm{Pb}$ ages of zircons from paragneiss clasts in a conglomerate from the Mino Belt, Kamiaso area, mostly yield ages in the range 1840 to
$1950 \mathrm{Ma}$, with some ages in excess of $2400 \mathrm{Ma}$ and as high as $3254 \pm 14 \mathrm{Ma}$ (Hidaka et al., 2002). Orthogneiss clasts from the same conglomerate represent the oldest rock in Japan, with whole-rock ages of $1985 \pm 25 \mathrm{Ma}\left(\mathrm{Rb}^{-}\right.$ Sr; Shibata and Adachi, 1974) and $2.07 \pm 0.06 \mathrm{Ga}\left(\mathrm{Sm}^{-}\right.$ Nd; Shimizu et al., 1996). CHIME zircon ages for the same rock yield dates of 1670 to $2050 \mathrm{Ma}$ and up to 3040 $\pm 180 \mathrm{Ma}$ (Adachi and Suzuki, 1993). The oldest dated igneous body is $502.5 \pm 9.6 \mathrm{Ma}$; this is a zircon $\mathrm{U}-\mathrm{Pb}$ (SHRIMP) date for the body of the Hikawa Granitoid, Kyushu (Sakashima et al., 2003). In terms of the K-Ar method, $592 \pm 24 \mathrm{Ma}$ (hornblende $\mathrm{K}$-Ar age) for an amphibolite body from the Nomo Peninsula, Kyushu, is the oldest recorded date in Japan (Hattori and Shibata, 1982). Although the gneiss and amphibolite on Oki-Dogo Island underwent metamorphism at around $240 \mathrm{Ma}$, which is coincident with metamorphism of the main part of the Hida gneiss, it is probable that the parent rocks of the Oki gneiss and amphibolite formed during the Early Proterozoic, and therefore may be the oldest body in Japan.

\section{CONCLUSIONS}

1) Gneisses on Oki-Dogo Island show a different age distribution of detrital zircons from gneiss in the Hida area.

2) The zircon ages of two paragneisses on Oki-Dogo Island are mainly around $1800 \mathrm{Ma}$ and 1900 to 2400 Ma.

3) The depositional ages of the parent sediments are not 250 to $350 \mathrm{Ma}$, but are much older, up to around $1600 \mathrm{Ma}$

4) In terms of the depositional or igneous age, the Oki gneiss is a candidate for the oldest rock body in the Japanese islands.

\section{ACKNOWLEDGMENTS}

The authors acknowledge critical reviews and comments on the manuscript by K. Suzuki and Y. Hiroi. We wish to express our sincere thanks to Mrs. M. Shigeoka of the National Science Museum for her help with sample preparation and SEM analysis. This paper is a contribution from the Hiroshima SHRIMP Laboratory, Hiroshima University, Japan.

\section{REFERENCES}

Adachi, M. and Suzuki, K. (1993) Were Precambrian gneiss clasts in the Kamiaso conglomerate derived from the eastern Korean Peninsula? Bulletin of the Nagoya University Furukawa Museum, 9, 25-45 (in Japanese with English abstract). 
Arakawa, Y., Saito, Y. and Amakawa, H. (2000) Crustal development of the Hida belt, Japan: Evidence from $\mathrm{Nd}-\mathrm{Sr}$ isotopic and chemical characteristics of igneous and metamorphic rocks. Tectonophysics, 328, 183-204.

Asano, M., Tanaka, T. and Suwa, K. (1990) Sm-Nd and Rb-Sr ages of the Hida metamorphic rocks in the Wada-gawa area, Toyama Prefecture. Journal of the Geological Society of Japan, 96, 957-966.

Biao, S., Nutman, A.P., Dunyi, L. and Jiashan, W. (1996) 3800 to $2500 \mathrm{Ma}$ crustal evolution in the Anshan area of Liaoning Province, northeastern China. Precambrian Research, 78, 7994.

Cheong, C. - S., Kwon, S.-T. and Park, K. ${ }^{-H}$. (2000) Pb and Nd isotopic constraints on Paleoproterozoic crustal evolution of the northeastern Yeongnam massif, South Korea. Precambrian Research, 102, 207-220.

Cherniak, D.J. and Watson, E.B. (2000) Pb diffusion in zircon. Chemical Geology, 172, 5-24.

Claoue-Long, J.C., Compston, W., Roberts, J. and Fanning, C.M. (1995) Two Carboniferous ages: a comparison of SHRIMP zircon dating with conventional zircon ages and ${ }^{40} \mathrm{Ar} /{ }^{39} \mathrm{Ar}$ analysis. In Geochronology, Time Scales and Global Stratigraphic Correlation (Berggren, A., Kent D.V., Aubly, M.-P., Hardenbol, J. Eds). Society for sedimentary Geology Special Publication, 54, Society for Sedimentary Geology, Tulsa, USA, 3-21.

Compston, W., Williams, I.S. and Meyer, C. (1984) U-Pb geochronology of zircons from lunar breccia 73217 using a sensitive high mass-resolution ion microprobe. Journal of Geophysical Research, 89: Supplement, B525-534.

Hattori, H. and Shibata, K. (1982) Radiometric dating of preNeogene granitic and metamorphic rocks in northwest Kyushu, Japan - with emphasis on geotectonics of the Nishisonogi zone. Bulletin of the Geological Survey of Japan, 33, 5784.

Hayase, I. and Ishizaka, K. (1967) Rb-Sr dating on the rocks in Japan (I), - South Western Japan - . The Journal of the Japanese Association of Mineralogists, Petrologists and Economic Geologists, 58, 201-212 (in Japanese with English abstract).

Hidaka, H., Shimizu, H., Adachi, M. (2002) U-Pb geochronology and REE geochemistry of zircons from Palaeoproterozoic paragneiss clasts in the Mesozoic Kamiaso conglomerate, central Japan: evidence for an Archean provenance. Chemical Geology, 187, 279-293.

Hiroi, Y. (1981) Subdivision of the Hida metamorphic complex, central Japan, and its bearing on the geology of the Far East in pre-Sea of Japan time. Tectonophysics, 76, 317-333.

Hoshino, M. (1979) Two-pyroxene amphibolites in Dogo Oki Islands. The Journal of the Japanese Association of Mineralogists, Petrologists and Economic Geologists, 74, 87-99.

Ishizaka, K. and Yamaguchi, M (1969) U-Th- Pb ages of sphene and zircon from the Hida metamorphic terrain, Japan. Earth and Planetary Science Letters, 6, 179-185.

Isozaki, Y. and Maruyama, S. (1991) Studies on Orogeny based on plate tectonics in Japan and new geotectonic subdivision of the Japanese Islands. Journal of Geography, 100, 697-761 (in Japanese with English abstract).

Kim, C.-B., Turek, A., Chang, H.W., Park, Y.S. and Ahn, K.-S. (1999) U-Pb zircon ages for Precambrian and Mesozoic plutonic rocks in the Seoul-Cheongju-Chooncheon area, Gyeonggi massif, Korea. Geochemical Journal, 33, 379-397.
Kwon, S.T. and Jeong, J.G. (1990) Preliminary Sr-Nd isotope study of the Hadong-Sanchung anorthositic rocks in Korea: implications for their origin and for the Precambrian tectonics. Journal of the Geological Society of Korea, 26, 341-349.

Lee, D.-S. (1987) Igneous activity. In Geology of Korea (Lee. D. - S. Ed.). Kyohak-Sa Publishing Co. Seoul, Korea, 289335.

Lee, J.K.W., Wiliams, I.S. and Ellis, D.J. (1997) Pb, U and Th diffusion in natural zircon. Nature, 390, 159-162.

Lee, S.R., Cho, M., Yi, K. and Stern, R.A (2000) Early Proterozoic granulites in central Korea: Tectonic correlation with Chinese cratons. Journal of Geology, 108, 729-738.

Maruyama, S and Seno, T. (1986) Orogeny and relative plate motions: example of the Japanese islands. Tectonophysics, 127, 305-329.

Ota, K. and Itaya, T. (1989) Radiometric ages of granitic and metamorphic rocks in the Hida metamorphic belt, central Japan. Bulletin of the Hiruzen Resurch Institute, Okayama University of Science, 15, 1-25 (in Japanese with English abstract).

Otofuji, Y. and Matsuda, T (1983) Paleomagnetic evidence for the clockwise rotation of Southwest Japan. Earth and Planetary Science Letters, 62, 349-359.

Ree, J.-H., Cho, M., Kwon, S.-T. and Nakamura, E. (1996) Possible eastward extension of Chinese collision belt in South Korea: The Imjingang belt. Geology, 24, 1071-1074.

Sagong, H., Cheong, C.-S. and Kwon, S.-T. (2003) Paleoproterozoic orogeny in South Korea: evidence from $\mathrm{Sm}-\mathrm{Nd}$ and $\mathrm{Pb}$ step-leaching garnet ages of Precambrian basement rocks. Precambrian Research, 122, 275-295.

Sakashima, T., Terada, K., Takeshita, T. and Sano, Y. (2003) Large-scale displacement along Median Tectonic Line, Japan: evidence from SHRIMP U-Pb dating of granites and gneisses from South Kitakami and paleo-Ryoke belts. Journal of Asian Earth Science, 21, 1019-1039.

Sano, Y., Terada, K., Hidaka, H., Yokoyama, K. and Nutman, A.P. (1999) Palaeoproterozoic thermal events recorded in the $\sim 4.0$ Ga Acasta gneiss, Canada: Evidence from SHRIMP U$\mathrm{Pb}$ dating of apatite and zircon. Geochimica et Cosmochimica Acta 63, 899-905.

Sano, Y., Hidaka, H., Terada, K., Shimizu, H. and Suzuki, M. (2000) Ion microprobe $\mathrm{U}-\mathrm{Pb}$ zircon geochronology of the Hida gneiss: Finding of the oldest minerals in Japan. Geochemical Journal 34, 135-153.

Sato, S. (1968) Precambrian-Variscan polymetamorphism in the Hida massif, basement of the Japanese Islands. Science reports of the Tokyo Kyoiku Daigaku. Sect. C 10, 15-130.

Shibata, K. and Adachi, M. (1974) Rb-Sr whole-rock ages of Precambrian metamorphic rocks in Kamiaso conglomerate from central Japan. Earth and Planetary Science Letters, 21, 277-287.

Shibata, K. and Nozawa, T. (1978) K-Ar ages of hornblends from the Hida metamorphic belt. The Journal of the Japanese Association of Mineralogists, Petrologists and Economic Geologists, 73, 137-141.

Shimizu, H., Lee, S.-G., Masuda, A. and Adachi, M. (1996) Geochemistry of $\mathrm{Nd}$ and $\mathrm{Ce}$ isotopes and REE abundances in Precambrian orthogneiss clasts from Kamiaso conglomerate, central Japan. Geochemical Journal, 30, 57-69.

Suzuki, M. (1977) Polymetamorphism in the Hida Metamorphic Belt, central Japan. Journal of science of the Hiroshima University, Series C, 7, 217-296.

Suzuki, K. and Adachi, M. (1991) The chemical Th-U-total Pb 
isochron ages of zircon and monazite from the Gray Granite of the Hida terrane, Japan. The Journal of earth sciences, Nagoya University, 38, 11-38.

Suzuki, K. and Adachi, M. (1994) Middle Precambrian detrital monazite and zircon from the Hida gneiss on the Oki-Dogo Island, Japan: their origin and implications for the correlation of basement gneiss of Southwest Japan amd Korea. Tectonophysics, 235, 277-292.

Tanaka, T. and Hoshino, M. (1987) Sm-Nd ages of Oki metamorphic rocks and their geological significance. Abstracts of the 94th annual meeting of the Geological Society of Japan, Geological Society of Japan, Tokyo, 492 (in Japanese).

Turek, A. and Kim C.-B. (1996) U-Pb zircon ages for Precambrian rocks in southwestern Ryeongnam and southwestern
Gyeonggi massifs, Korea. Geochemical Journal, 30, 231249.

Wang, H. (1986) Geotectonic development. In, The Geology of China (Yang, Z. et al. Ed.). Clarendon Press, Oxford, UK, 256-275.

Zhao, G., Wilde, S.A., Cawood, P.A. and Sun M. (2001) Archean blocks and their boundaries in the North China Craton: lithological, geochemical, structural and $\mathrm{P}-\mathrm{T}$ path constraints and tectonic evolution. Precambrian Research, 107, 45-73.

Manuscript received January 27, 2006

Manuscript accepted June 2, 2006

Published online November 24, 2006

Manuscript handled by Makoto Arima 